\title{
Correlates of Aggregate Support for the Radical Right in Portugal
}

\author{
Alexandre Afonso, Leiden University
}

\begin{abstract}
This research note explains variation in local aggregate support for the populist radical right in Portugal, a country long considered immune to the rise of this political force. Using local electoral results of the 2021 presidential election, I find positive statistical associations between the radical right vote share and the share of social assistance benefit recipients, as well as with the size of the local Roma minority. I also show that the effect of the percentage of social assistance recipients is conditioned on a higher size of the local Roma minority. In contrast, factors such as unemployment, average income levels or the share of immigrants and their change over time do not explain variation in radical right vote shares. The research points to the presence of outgroups that can be construed as "outsiders" as a relevant factor explaining aggregate support for the radical right in contexts where the salience of immigration is low.
\end{abstract}

Keywords: Portugal; Chega; Radical Right; Roma minorities

Words: 4450

\section{Introduction}

Portugal has long been considered an exception in Europe because of the absence of a significant radical right party (Alonso and Kaltwasser, 2015, p. 23; Mendes and Dennison, 2020). This outlier status came to an end with the emergence of Chega (Enough!) in 2019. While this party only gathered $1.3 \%$ of the vote in the legislative elections of 2019, gaining one MP, its leader André Ventura won $11.9 \%$ of the vote in the presidential election of January 2021, coming third within one point of the second candidate and ahead of those of a number of established parties. Never before had a radical right party obtained such a high score in a national election in Portugal. In this context, it is important to understand the drivers of support for this new phenomenon in a country hitherto devoid of a substantial political force on the far right of the political spectrum, and where the salience of immigration has been low (Carvalho and Duarte, 2020; Mendes and Dennison, 2020).

This research note uses electoral data at the local level to explain variation in the vote share of the radical right candidate across Portuguese municipalities in the Presidential elections of January 242021 , showing how the size of outgroups (the Roma and social assistance recipients) is associated with higher vote shares for the radical right. The contribution of the article is twofold. First, in the Western European context, we know little about the drivers of radical right support in countries where this phenomenon is new, and where immigration plays a smaller role in political conflicts. Looking at the case of Vox, Turnbull-Dugarte et al. (2020) find that the individual drivers of support for Vox are different from those of other more established radical right parties in Northern Europe, especially when it comes to the economic status of its supporters. Moreover, recent research has shown that Portugal was the European 
country (out of seven) with the lowest level of politicisation of immigration (Carvalho and Duarte, 2020, pp. 1477-78). In this context, the success of Chega is puzzling in the light of existing research finding that "no populist right party performed well [...] without mobilizing grievances over immigration" (Ivarsflaten, 2008, p. 3).

This article is to our knowledge the first to investigate correlates of support for the radical right in Portugal. While much of the literature uses individual surveys, here I use actual local election results combined with socio-demographic data to shed light on the environmental factors that can influence radical right support, and notably the role and size of "outgroups". Any observational analysis based on aggregate data should admittedly entail the usual caveats about ecological fallacies and causality. However, an exploratory look at correlations in real electoral contexts provides valuable insights into the drivers of support for the radical right, and most importantly, help structure hypotheses for further research.

\section{The Radical Right in Portugal}

Portugal has long been considered immune to the rise of the radical right, the party family espousing authoritarianism, nativism and populism that has made the fastest electoral gains in European countries in recent decades (Golder, 2016, p. 477; Mudde, 2007). Alonso and Kaltwasser (2015, p. 23) highlighted in 2015 that Spain and Portugal were the only countries they had reviewed where the radical right had never won more than $1 \%$ in national elections. The absence of a meaningful radical right party has been explained by the authoritarian past which may have "vaccinated" the Portuguese political system against such forces, or the low salience of immigration, one of the core issues on the agenda of these parties (Mendes and Dennison, 2020, p. 15). Political parties on the far right of the political spectrum, such as the Partido Nacional Renovador, had so far occupied only a very marginal role (da Costa, 2011, p. 783).

This configuration changed in recent years with the rise of Chega, the party founded by André Ventura (Marchi, 2020). In the 2019 legislative election, this party won only $1.29 \%$ of the vote on a platform proposing, among others, the chemical castration for sex offenders, harsher sentences for corruption cases, and the deportation of illegal immigrants (Fernandes and Magalhães, 2020, p. 1041). After this timid start, however, the presidential election of January 2021 was a breakthrough in the history of the radical right in Portugal. Ventura won $11.9 \%$ of the vote, coming a close third behind the centre-right incumbent Marcelo Rebelo de Sousa (PSD) and only one point behind the centre-left candidate Ana Gomes. The party made significant electoral gains in the interior of the country, and in the southern region of Alentejo (Figure 1). Most significantly, Chega gathered more votes than a number of the candidates of parties long established in the Portuguese political system, such as the Communist Party, the Left Bloc and the conservative CDS-PP, sparking debates about a reconfiguration of possible alliances on the right of the party system. 
Figure 1: Vote Share of Chega in the 2021 Portuguese Presidential Election (\%)

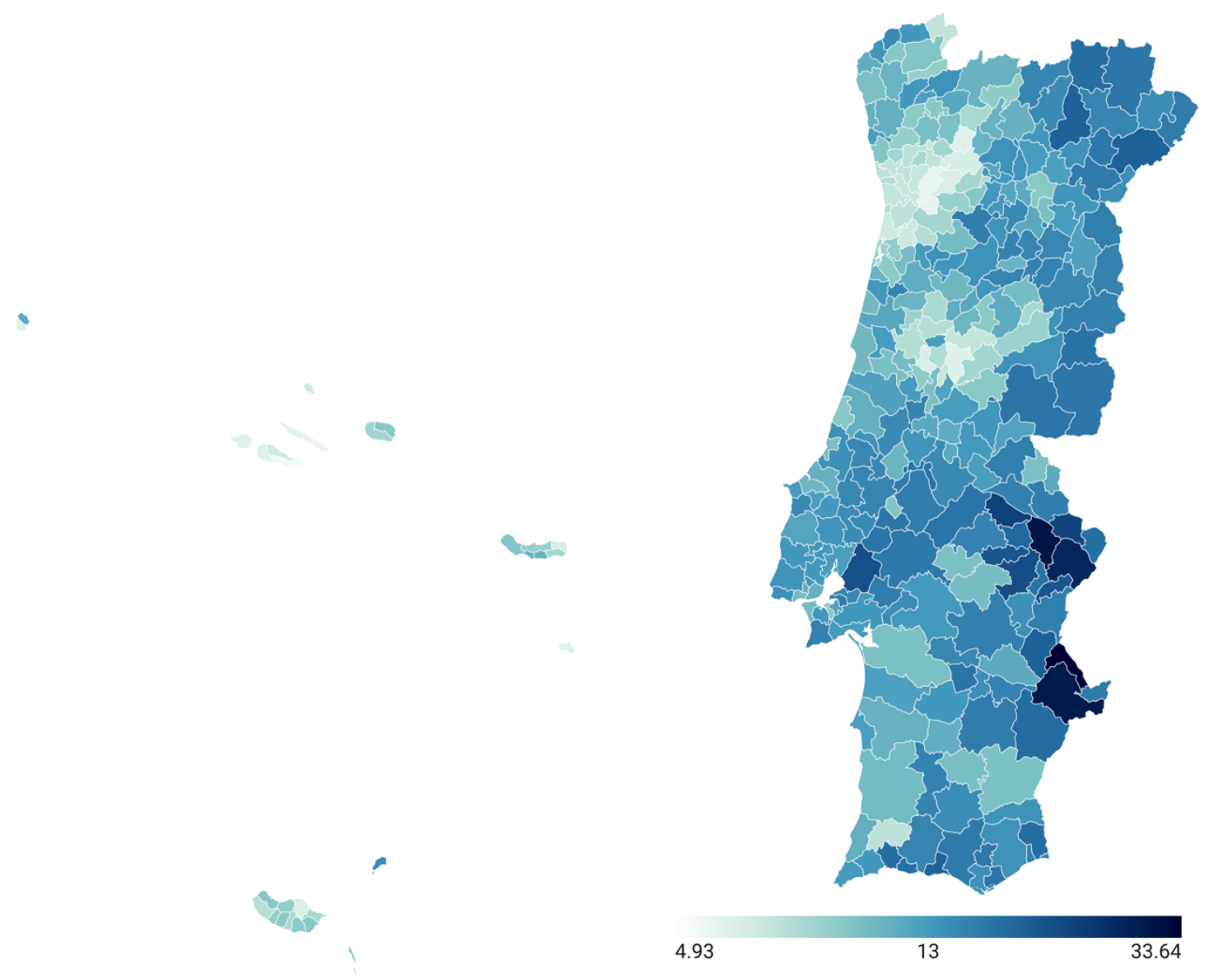

Own elaboration based on data by mai.gov.pt. Made with Datawrapper.

Chega displays many familiar traits of populist radical right parties in Europe. Its leader André Ventura is a former PSD politician, law professor and football commentator. The core campaign issues on which the party focuses are national sovereignty, law and order, a critique of the political establishment and a restrictive stance on immigration (Marchi, 2020). Within the context of the comparatively low salience of immigration in Portugal (Carvalho and Duarte, 2020; Mendes and Dennison, 2020, p. 19), one of its main specificities has been its focus on the Roma community. The Portuguese Roma community (ciganos) represents about 40,000-60,000 individuals (0,52\%) (Mendes et al., 2014, pp. 12-13). As elsewhere in Europe, it is a highly stigmatized community with high poverty rates, often living in poor housing conditions (camps, tents and makeshift accommodation) and with high rates of welfare 
dependency. ${ }^{1}$ The council of Europe reported that the Portuguese Roma "continue to be subjected to direct and indirect discrimination and continue to live on the margins of society, in at times very poor housing conditions, with a lower life expectancy than the rest of the population, with a lower school enrolment and educational performance, in particular for Roma girls, as well as with a high level of unemployment" (Council of Europe, 2019, p. 1). Chega and its leader have often emphasized welfare dependency and other social problems within this community as an electoral campaign argument (Lusa, 2020).

As the rise of a sizeable radical right party in Portugal is a new phenomenon, research on its characteristics has been scarce. Besides Mendes and Dennison (2020), Marchi (2020) provides a comprehensive account in Portuguese of the emergence, organization and ideological traits of the Chega party. So far, research on its electoral drivers has lacked data in real electoral contexts to investigate the drivers of radical support in Portugal. This research note is a first attempt to look at the contextual factors influencing the strength of the radical right vote across electoral constituencies in Portugal. In future, more complete research should combine individual and contextual evidence to understand the drivers of radical support in Portugal, but a contextual analysis can shed light on the environmental factors that shape individual choice (Arzheimer, 2009; Knigge, 1998; Stockemer, 2018).

\section{Explaining Radical Right Support: Economic Deprivation and Group Conflict}

There are have been different views on the drivers of support for the radical right. On the demand (voter) side, authors have focused on modernisation, economic or cultural grievances (Golder, 2016, pp. 482 485). Here, I focus on the latter two as they are the ones that can be tested in a cross-sectional setting using aggregate data.

In the perspective of economic grievances, individuals may be more likely to support radical right and anti-system parties in contexts of economic deprivation: where unemployment is higher, incomes lower or which have been on a trajectory of economic stagnation or decline. In these contexts, we would expect the appeal of populist right-wing parties to be most effective as their discourse mobilising popular discontent against "the establishment" can find a more fertile ground when jobs are scarce and incomes low (Arzheimer, 2009; Jackman and Volpert, 1996, p. 507). This has notably been a common narrative in the United Kingdom with the Brexit and UKIP vote finding large bases of support in the deindustrialised North compared to dynamic London (Jennings et al., 2017, p. IV). In the United States, Donald Trump found a base of support in the "Rust Belt" marked by stagnant incomes and high unemployment. Along these lines, the appeal of the radical right can also be boosted in areas with higher

\footnotetext{
${ }^{1}$ The estimated share of Roma recipients of the RSI (minimum income of insertion) was 3.8\%, while their share in the total population was about $0.6 \%$ (Poligrafo, 2019)
} 
levels of welfare dependency, as welfare recipients can be framed as "takers" using hard-earned money from "hard-working" taxpayers (Ennser-Jedenastik, 2016; Rathgeb, 2021).

Hypothesis 1: Support for the Portuguese radical right is higher in areas characterised by economic deprivation measured in terms of incomes, unemployment, or welfare dependency, or changes thereof The second approach focuses on group conflict and the presence of minority groups - typically immigrants - that can serve as target of cultural grievances (Stockemer, 2018, p. 608). There are different ideas about how the availability and size of minority groups can influence radical right support. One the one hand, group contact theory assumes that increased contact between majority and minority groups facilitates mutual understanding and diminishes the feeling of group threat, thereby lowering support for parties that seek to capitalize on such sentiments. In the United Kingdom, the highest levels of support for Brexit and the UKIP or Brexit party could be observed in constituencies with less ethnically diverse populations (Jennings et al., 2017, p. 4).

On the other hand, higher shares of ethnic minority individuals, or changes thereof, can lead to more prevalent feelings of group threat and a greater ability of radical right parties to mobilise voters (see, e.g Knigge, 1998, p. 267). We could expect this phenomenon to be more prevalent when it comes to ethnic minorities that are particularly stigmatized or different from the majority in terms of their social circumstances or lifestyle. The Roma in Portugal are a case in point. Following this idea, we could expect support for the radical right in Portugal to be greater in areas where the share of immigrants or the size of the Roma minority is greater.

Hypothesis 2: Support for the Portuguese radical right is greater in areas where the relative size of ethnic minorities is larger.

Finally, one could also argue that radical right support is shaped by a combination of cultural and economic factors, or more precisely that the effect of economic factors is conditioned on cultural factors and vice-versa. Bolet (2020) looks for instance at the role of labour market competition between natives and immigrants and unemployment and finds an amplifying effect. Drawing on this, we could assume that radical right support is shaped by the combination of cultural and economic factors rather than these exerting an influence separately. For instance, higher unemployment may be associated with higher levels of support for the radical right if the share of immigrants is high; higher levels of welfare dependency may be associated with higher support for the radical right if the proportion of ethnic minorities is high.

Hypothesis 3: Higher levels of support for the radical right in Portugal are associated with higher economic deprivation if the proportion of ethnic minorities is higher 


\section{Data and Methods}

I use cross-sectional OLS regressions to explain the vote share of the radical right party candidate André Ventura across Portuguese municipalities in the January 2021 presidential elections. ${ }^{2}$ The radical-right party vote share at the level of the municipality is regressed on a number of economic, demographic and social indicators measured at the same level. The units of analysis are Portuguese local authorities (municipios). There are 308 such local authorities varying widely in size, from 464 inhabitants (on the island of Corvo in the Azores) to 509'000 in Lisbon. This is the lowest unit of analysis for which we have disaggregated socio-economic data. Portuguese municipalities are further disaggregated in lowerlevel 3092 civil parishes (freguesias) for which we would have electoral data but no socio-demographic data.

The dependent variable of the analysis is the vote share obtained in each municipality by the populist radical right candidate André Ventura in these elections. This data is extracted from the election platform of the ministry of the interior. ${ }^{3}$ This level of analysis is considered pertinent as the municipality is the level at which citizens should observe economic, social and demographic developments shaping their vote choice.

Most of the independent variables are extracted from the Pordata platform, which compiles data from the Portuguese national institute of statistics (INE) in a more readily available form at the municipal level, often drawn from census data. One problem of the census is that the data can be somewhat old (the last one was conducted in 2011) but is of high quality. Regarding economic variables, I use the average monthly income in EUR in 2018 (the last available year as the time of writing), the change in the average monthly income between 2010 and 2018 to capture whether incomes have been falling, stagnating of increasing, as well as the share of unemployed individuals in each municipality in December 2020 available from the Portuguese public employment service (IEFP, 2020). Change since 2015 is also included to capture trajectories of decline or growth. ${ }^{4}$ For welfare recipiency, I include the share of recipients of the RSI (Rendimento Social de Inserção), an income support scheme aimed at individuals in extreme poverty. I also include house prices in 2020 from the INE and their evolution of time since 2017; this indicator is especially suitable to capture the territorial cleavage between the more expensive coast and the cheaper interior of the country.

For the group threat hypotheses, I use the percentage of foreign nationals per municipality. Because anti-immigration grievances in Portugal are focused on specific groups of migrants, notably those from

\footnotetext{
${ }^{2}$ Tobit models are an alternatives method used to explain vote shares that accounts for the boundedness of the dependent variable (see Grant and Tilley, 2019). Tobit models are included in the Appendix as robustness tests but do not change the results. Here I show simple OLS regressions as they are easier to interpret.

${ }^{3} \mathrm{https}: / /$ www.eleicoes.mai.gov.pt/

${ }^{4}$ Data for this indicator only includes continental Portugal, without Azores and Madeira
} 
African countries - notably former colonies such as Cape Verde, Angola, Mozambique or Guiné-Bissau - I also use the share of foreign nationals from African countries. Data on the estimated size of the Roma minority by municipality in 2013 and 2014 was obtained from the national institute for housing and urban rehabilitation (IHRU), which produced a report on the housing conditions of Roma individuals in 2015 (IHRU, 2015, p. 9). This data should be used with some caution as it was collected from estimates by local mayors; these estimates might be influenced by local perceptions about this community, and it may be the case that greater concerns about the "problem" of the Roma may lead to an overestimation in the size of this minority at the local level. The subjective dimension is nevertheless perhaps as important as the objective one here, as will discussed in the conclusion.

I control for a number of potential confounders: population size, population density as a measure of the rural/urban dimension, the percentage of residents with secondary education; the age structure (a ratio of the number of people above 65 for each 100 people below 15), crime rates as another factor featuring prominently in the agenda of radical right parties, and the incidence of Covid in each municipality on 19.1.2021 (DSSG - PT, 2021), as this was such an overwhelming political issue at the time of the election. 
Table 1: OLS regression estimates predicting radical right vote shares across Portuguese municipalities in the 2021 Presidential election

\begin{tabular}{|c|c|c|c|c|c|c|c|c|c|c|c|c|}
\hline & (1) & & (2) & & (3) & & (4) & & (5) & & (6) & \\
\hline & Model 1 & $\mathrm{SE}$ & $\begin{array}{l}\text { Model } 2 \\
\end{array}$ & $\mathrm{SE}$ & Model 3 & $\mathrm{SE}$ & Model 4 & SE & Model 5 & $\mathrm{SE}$ & Model 6 & $\mathrm{SE}$ \\
\hline Population (thousands) & $-0.0163^{\prime \prime \prime}$ & $(0.00554)$ & $-0.0153^{\mathrm{m} m}$ & $(0.00538)$ & $-0.0145^{\prime \prime \prime}$ & $(0.00446)$ & $-0.0134^{* * *}$ & $(0.00512)$ & $-0.0133^{* *}$ & $(0.00513)$ & $-0.0125^{*}$ & $(0.00505)$ \\
\hline $\begin{array}{l}\text { \% secondary education as highest } \\
\text { diploma }\end{array}$ & $0.564^{m+m}$ & $(0.0903)$ & $0.707^{* * * * *}$ & $(0.116)$ & $0.456^{* * * *}$ & $(0.0829)$ & $0.574^{* * *+4}$ & $(0.116)$ & $0.572^{* *+*}$ & $(0.116)$ & $0.595^{5^{* * * *}}$ & $(0.114)$ \\
\hline Elderly ratio & $0.0108^{* * *}$ & $(0.00249)$ & $0.0119^{m * *}$ & $(0.00286)$ & $0.00633^{* *}$ & $(0.00206)$ & $0.00854^{* \prime *}$ & $(0.00282)$ & $0.00856^{* *}$ & $(0.00282)$ & $0.0100^{\circ * * *}$ & $(0.00281)$ \\
\hline Crime rate & 0.0370 & $(0.0231)$ & 0.0176 & $(0.0262)$ & 0.00811 & $(0.0216)$ & -0.00151 & $(0.0254)$ & -0.00557 & $(0.0259)$ & 0.0135 & $(0.0255)$ \\
\hline Population density & -0.000622 & $\begin{array}{l}(0.000353) \\
\end{array}$ & $-0.000974^{* * *}$ & $\begin{array}{l}(0.000330) \\
\end{array}$ & $-0.000744^{*}$ & $\begin{array}{l}(0.000303) \\
\end{array}$ & $-0.000853^{*}$ & $\begin{array}{l}(0.000334) \\
\end{array}$ & $-0.000841^{*}$ & $\begin{array}{l}(0.000334) \\
\end{array}$ & $-0.000805^{*}$ & $(0.000329)$ \\
\hline Incidence of Covid (log) & $1.375^{* * * *}$ & $(0.259)$ & $1.321^{* * * *}$ & $(0.353)$ & $0.997^{* *+*}$ & $(0.209)$ & $1.045^{* *}$ & $(0.332)$ & $1.008^{* *}$ & $(0.336)$ & $1.071^{* *}$ & $(0.327)$ \\
\hline$\%$ social assistance recipients & & & $1.194^{\text {wath }}$ & $(0.139)$ & & & $0.505^{\text {s* }}$ & $(0.162)$ & $0.542^{* *}$ & $(0.167)$ & 0.234 & $(0.182)$ \\
\hline Mean monthly income 2018 & & & -0.00131 & $(0.00155)$ & & & -0.00105 & $(0.00147)$ & -0.00102 & $\begin{array}{ll}(0.00148) \\
\end{array}$ & -0.00110 & $(0.00145)$ \\
\hline $\begin{array}{l}\text { Change in mean monthly income } \\
(2010-2018)\end{array}$ & & & -0.0410 & $(0.0316)$ & & & -0.0179 & $(0.0299)$ & -0.0208 & $(0.0301)$ & -0.0197 & $(0.0294)$ \\
\hline$\%$ unemployed in population & & & -0.325 & $(0.179)$ & & & -0.0737 & $(0.173)$ & $\begin{array}{l}-0.154 \\
\end{array}$ & $\begin{array}{ll}(0.198) \\
\end{array}$ & 0.0554 & $(0.175)$ \\
\hline $\begin{array}{l}\text { Change in unemployment rate 2015- } \\
2020\end{array}$ & & & 0.356 & $(0.195)$ & & & 0.0817 & $(0.185)$ & 0.127 & $(0.193)$ & $\begin{array}{l}-0.0380 \\
\end{array}$ & $(0.186)$ \\
\hline Median house price (2020) & & & 0.000324 & $(0.000910)$ & & & -0.000161 & $(0.000961)$ & -0.0000537 & $(0.000970)$ & -0.000312 & $(0.000947)$ \\
\hline Change in house prices 2017-2020 & & & 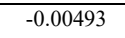 & $(0.00640)$ & & & -0.00810 & $(0.00593)$ & -0.00775 & $(0.00594)$ & -0.0113 & $(0.00592)$ \\
\hline Percent Roma (2014) & & & & & $2.406^{* * * *}$ & $(0.188)$ & $1.806^{* *+4}$ & $(0.254)$ & $1.785^{\mathrm{wN+7}}$ & $(0.256)$ & $1.056^{* *}$ & $(0.351)$ \\
\hline$\%$ foreign nationals 2019 & & & & & 0.0243 & $(0.0447)$ & 0.0453 & $(0.0612)$ & -0.0125 & $(0.0919)$ & 0.0187 & $(0.0609)$ \\
\hline $\begin{array}{l}\text { Change in proportion of foreign } \\
\text { nationals 2010-2019 }\end{array}$ & & & & & -0.00114 & $(0.00163)$ & -0.000902 & $(0.00185)$ & -0.000666 & $\begin{array}{ll}(0.00188) \\
\end{array}$ & -0.00129 & $(0.00183)$ \\
\hline$\%$ National from African countries & & & & & 0.477 & $(0.328)$ & 0.483 & $(0.348)$ & 0.475 & $\begin{array}{l}(0.348) \\
\end{array}$ & 0.540 & $(0.343)$ \\
\hline $\begin{array}{l}\text { \% foreign nationals } 2019 \# \% \\
\text { unemployed in population }\end{array}$ & & & & & & & & & 0.00816 & $\begin{array}{ll}(0.00968) \\
\end{array}$ & & \\
\hline $\begin{array}{l}\text { Percent Roma (2014) \# \% social } \\
\text { assistance recipients }\end{array}$ & & & & & & & & & & & $0.122^{* *}$ & $(0.0400)$ \\
\hline Constant & $-6.314^{* * *}$ & $(2.153)$ & $-7.386^{*}$ & (3.693) & -1.947 & $(1.837)$ & -3.232 & $(3.485)$ & -2.586 & $(3.570)$ & -3.888 & $(3.436)$ \\
\hline Observations & 300 & & 272 & & 300 & & 272 & & 272 & & 272 & \\
\hline$R^{2}$ & 0.267 & & 0.434 & & 0.544 & & 0.538 & & 0.540 & & 0.555 & \\
\hline
\end{tabular}

Standard errors in parentheses ${ }^{*} p<0.05,{ }^{* *} p<0.01,{ }^{* * *} p<0.001$ 


\section{Results}

The results of the regression analysis are presented in Table 1. Model 1 contains only the controls and explains about $27 \%$ of the variance. We can see a statistically significant negative effect of population size, of the age dependency ratio (an older population is associated with higher radical right vote shares), and a positive association with the share of the population with a secondary degree. This latter finding is consistent with research on voters of Vox in Spain, where upper secondary education is associated with a higher probability of voting radical right (Turnbull-Dugarte et al., 2020, p. 12). Population density gains significance with a negative sign when we include the independent variables in subsequent models, meaning that rurality has a positive effect on the radical right vote share. The Covid incidence rate has a positive effect significant across all the models, meaning perhaps that areas with a higher Covid incidence were more likely to blame the government for failing to control the virus and support an anti-system candidate. Crime rates do not have an effect in any of the models.

Model 2 adds the economic variables. The only economic variable that has a significant statistical relationship at the standard levels is the percentage of social assistance recipients (positive). In this model, a 1 percentage point increase in the share of social assistance recipients results in a 1.2 percentage point increase in the radical right vote share. In contrast, the unemployment rate, the mean income and house prices, as well as their change over time, do not reach significance. Hence, all other things being equal, municipalities with a lower income, a higher unemployment rate or lower house prices are not more likely to have higher radical right vote shares, nor do municipalities where incomes and house prices have increased less than average.

Model 3 includes the controls and the group conflict variables, namely the estimated size of the Roma minority, the percentage of foreign nationals, the change in the share of foreign nationals in the last 10 years, as well as the percentage of immigrants from African countries. The effect is significant and surprisingly large when it comes to the size of the Roma minority. Controlling for other factors, a 1 percentage point increase in the share of the Roma minority is associated with a 2.4 percentage point increase in the vote share of the radical right candidate; in the full model controlling for all factors, this effect declines somewhat to 1.8 percentage points, but it stays nevertheless fairly large and significant. In contrast, the percentage of foreign nationals of all nationalities or its change over time has no discernible effect on the vote share of the radical right.

Model 4 includes all the variables and explains about $54 \%$ of the total variation in the radical right vote share across municipalities. Controls set aside, the size of the Roma minority and the proportion of social assistance benefit recipients appear as strong predictors of the radical right vote share. In some way, both these groups can be constructed as "outsiders" and have been prominent targets of the discourse of the Chega party in its electoral campaigns. This appeal seems to have materialized at the local level. Figure 3 shows predictive margins for two relevant variables included in the full model. 
Figure 2: Predictive margins with 95\% confidence intervals at different levels of selected independent variables (full model)
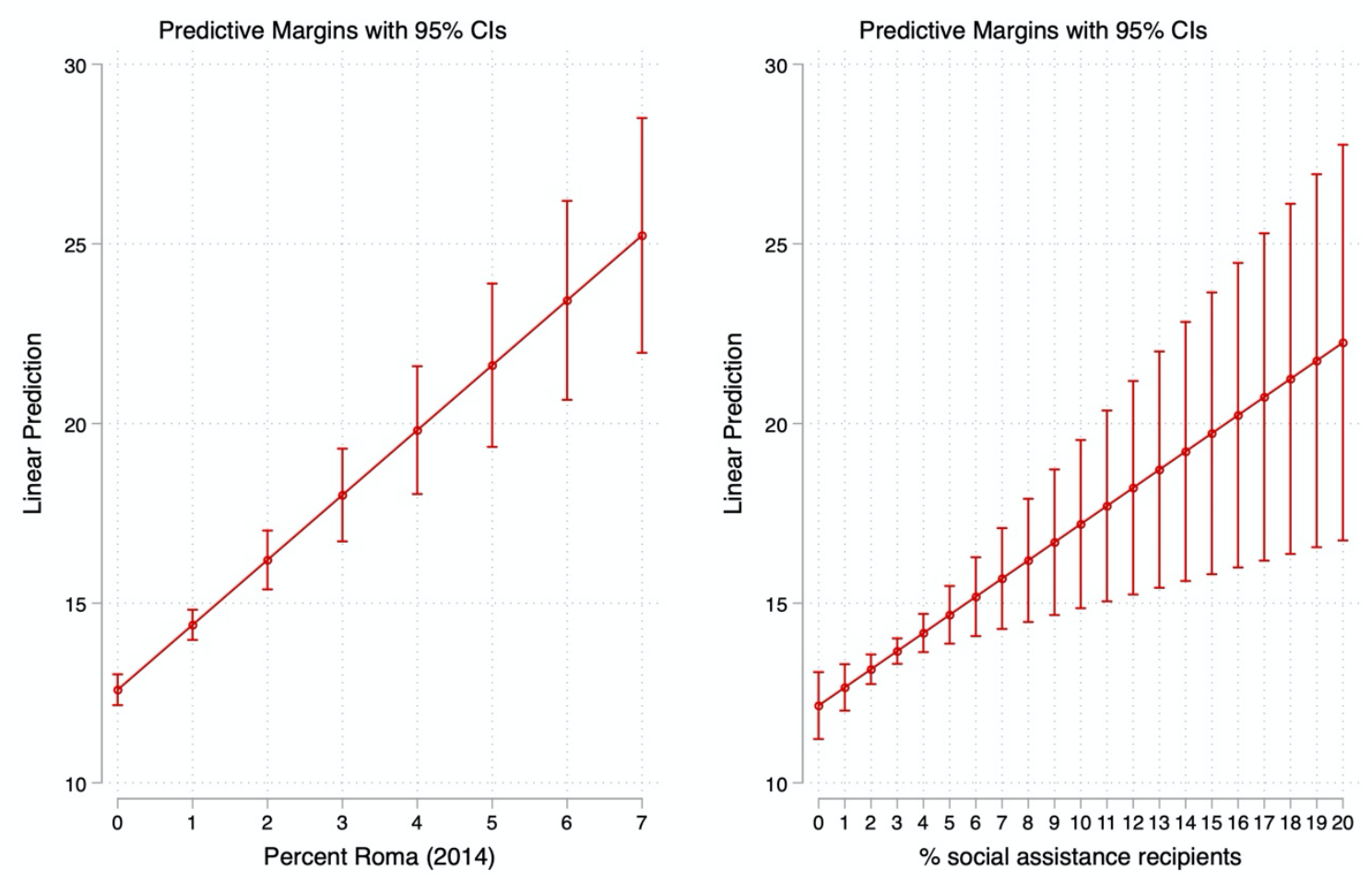

The last two models contain interactions between economic and group conflict variables, namely between the percentage of foreign nationals and the unemployment rate (Model 5), and between the percentage of Roma individuals and the percentage of social assistance recipients (Model 6). While the impact of foreign nationals on the radical right vote share does not change at different levels of unemployment - the interaction in Model 5 is not significant - we can observe in Model 6 that the impact of social assistance recipiency is substantially moderated by the size of the Roma minority. The relative size of the Roma minority stays positive and significant across all models, while social assistance recipiency only seems to have an effect if it is combined with this Roma variable. Figure 3, which plots predicted margins for Model 6, shows that the aggregate vote share of the radical right does not increase significantly with higher percentages of social assistance recipients when the percentage of individuals of the Roma minority is zero. However, it does increase very significantly when this percentage is high. In other words, radical right support does not increase substantially with welfare recipiency alone, but when it is combined with higher shares of ethnic minority individuals. The same Figure 3 shows that the percentage of the Roma minority has an impact on its own, but this impact is amplified with high levels of welfare dependency. One possible causal mechanism would be that higher social assistance recipiency results in higher vote shares for the radical right when these benefits are 
believed to mostly benefit ethnic minority individuals. Research with individual survey data - or even experimental data - would be needed to ascertain these mechanisms precisely at the individual level.

\section{Figure 3: Predictive margins for interaction between percentage of social assistance recipients} and the estimated size of the Roma minority in \%
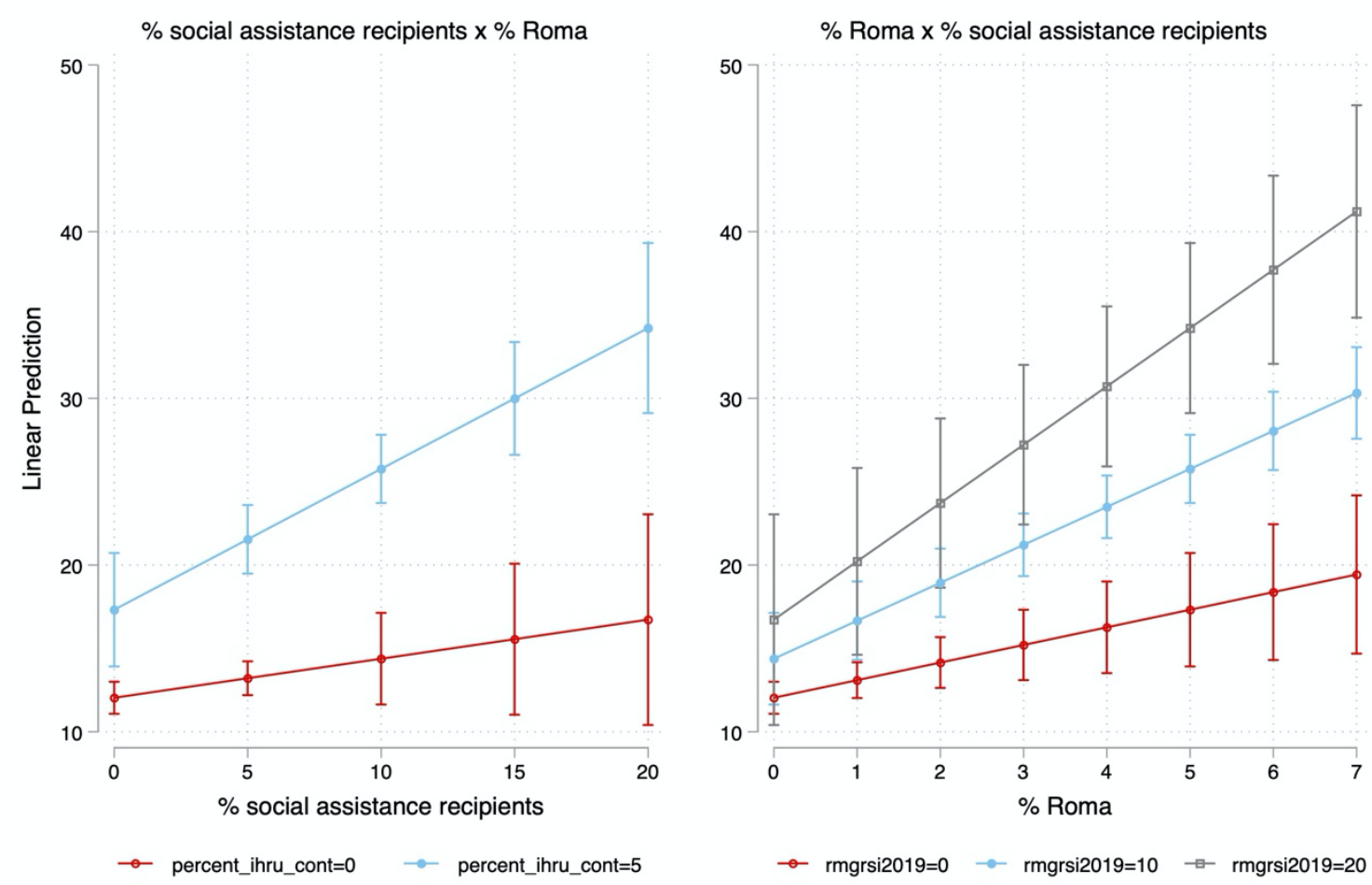

\section{Conclusion}

This paper has sought to explain variation in the radical right vote share across municipalities in Portugal in the first election where this political force made an electoral breakthrough. I showed that controlling for a number of other factors, the size of the Roma minority across municipalities and the percentage of social assistance recipients are associated with higher radical right vote shares; combined, these two factors seem to amplify each other. In contrast, variables often believed to foster anti-system parties within the "economic anxiety" narrative, such as unemployment or income stagnation do not seem to have a significant effect. Another important finding is the lack of demonstrable effect of the size of immigrant minorities on aggregate support for the radical right. In a context where the salience of immigration is low, mobilizing the electorate against other, more stigmatised minorities such as the Roma seems more effective in terms of electoral outcomes at the local level.

One limit of the analysis is the subjective nature of the measure of the size of the Roma minority since it is based on local estimates by mayors, and therefore subject to bias. Hence, it may be that the effect is overestimated: high levels of latent anti-Roma sentiment may result both in an overestimation in their 
numbers and higher levels of support for the radical right. Nevertheless, even if we consider this indicator as a perception rather than an objective measurement, its strong and positive association with radical right vote shares is nevertheless informative. It shows that the (real or perceived) size of groups that can be politically constructed as "outsiders" at the local level are associated with a higher vote share for the radical right even controlling for a number of confounders. In some way, the results show that the appeals of radical right parties around dichotomies such as "makers" and "takers" (Rathgeb, 2021) do have a material basis at the local level at least in the Portuguese context.

Obviously, these results should be confirmed with individual survey data. While ecological and causal inferences should be made with a great deal of caution, this analysis could serve as a starting point to investigate individual support for the radical right in countries without a history of mass foreign migration and no established radical right tradition. Because of the relevance of the Roma minority, it may be interesting to investigate whether similar drivers of support are present in central and Eastern Europe, where this issue is also politicised. Finally, a more comprehensive analysis of the drivers of radical right support should look at the interaction of individual and environmental factors in a multilevel research design.

\section{References}

Alonso, S., Kaltwasser, C.R., 2015. Spain: No Country for the Populist Radical Right? South European Society and Politics 20, 21-45. https://doi.org/10.1080/13608746.2014.985448

Arzheimer, K., 2009. Contextual Factors and the Extreme Right Vote in Western Europe, 1980-2002. American Journal of Political Science 53, 259-275. https://doi.org/10.1111/j.15405907.2009.00369.x

Bolet, D., 2020. Local labour market competition and radical right voting: Evidence from France. European Journal of Political Research 59, 817-841. https://doi.org/10.1111/1475-6765.12378

Carvalho, J., Duarte, M.C., 2020. The Politicization of Immigration in Portugal between 1995 and 2014:

A European Exception? JCMS: Journal of Common Market Studies 58, 1469-1487. https://doi.org/10.1111/jcms. 13048

Council of Europe, 2019. Advisory committee on the framework convention for the protection of national minorities - Fourth Opinion on Portugal adopted on 28 June 2019. Council of Europe.

da Costa, J.M., 2011. O Partido Nacional Renovador: a nova extrema-direita na democracia portuguesa. Análise Social 46, 765-787.

DSSG - PT, 2021. Dados relativos à pandemia COVID-19 em Portugal. Data Science for Social Good Portugal. 
Ennser-Jedenastik, L., 2016. A Welfare State for Whom? A Group-based Account of the Austrian Freedom Party's Social Policy Profile. Swiss Political Science Review 22, 409-427. https://doi.org/10.1111/spsr.12218

Fernandes, J.M., Magalhães, P.C., 2020. The 2019 Portuguese general elections. West European Politics 43, 1038-1050. https://doi.org/10.1080/01402382.2019.1702301

Golder, M., 2016. Far Right Parties in Europe. Annual Review of Political Science 19, 477-497. https://doi.org/10.1146/annurev-polisci-042814-012441

Grant, Z.P., Tilley, J., 2019. Fertile soil: explaining variation in the success of Green parties. West European Politics 42, 495-516. https://doi.org/10.1080/01402382.2018.1521673

IEFP, 2020. Estatísticas Mensais por Concelhos [WWW Document]. URL https://www.iefp.pt/documents/10181/9774394/SIE+-

+Desemprego+registado+por+concelhos+dezembro+2020.ods/c929078e-899a-488f-9599c931e90f30f3 (accessed 2.5.21).

IHRU, 2015. Caracterização das Condições de Habitação das Comunidades Ciganas Residentes em Portugal. Instituto da Habitação e da Reabilitação Urbana, Lisbon.

Ivarsflaten, E., 2008. What Unites Right-Wing Populists in Western Europe?: Re-Examining Grievance Mobilization Models in Seven Successful Cases. Comparative Political Studies 41, 3-23. https://doi.org/10.1177/0010414006294168

Jackman, R.W., Volpert, K., 1996. Conditions Favouring Parties of the Extreme Right in Western Europe. British Journal of Political Science 26, 501-521.

Jennings, W., Brett, W., Bua, A., Laurence, R., 2017. Cities and towns: the 2017 general election and the social divisions of place. New Economics Foundation, London.

Knigge, P., 1998. The ecological correlates of right-wing extremism in Western Europe. European Journal of Political Research 34, 249-279. https://doi.org/10.1023/A:1006953714624

Lusa, 2020. André Ventura multado em mais de 400 euros por discriminar ciganos. PÚBLICO.

Marchi, R., 2020. A nova direita anti-sistema: o caso do Chega. Edições 70, Lisboa, Portugal.

Mendes, M., Magano, O., Candeias, P., 2014. Estudo nacional sobre as comunidades ciganas, Estudo nacional sobre as comunidades ciganas. Alto Comissariado para as Imigrações.

Mendes, M.S., Dennison, J., 2020. Explaining the emergence of the radical right in Spain and Portugal: salience, stigma and supply. West European Politics 0, 1-24. https://doi.org/10.1080/01402382.2020.1777504

Mudde, C., 2007. Populist radical right parties in Europe. Cambridge University Press, Cambridge.

Poligrafo, 2019. Apenas 3,8\% dos beneficiários de RSI são de etnia cigana? (COM VÍDEO) [WWW Document]. Polígrafo. URL https://poligrafo.sapo.pt/fact-check/apenas-38-dos-beneficiariosde-rsi-sao-de-etnia-cigana (accessed 5.7.21). 
Rathgeb, P., 2021. Makers against takers: the socio-economic ideology and policy of the Austrian Freedom Party. West European Politics 44, 635-660. https://doi.org/10.1080/01402382.2020.1720400

Stockemer, D., 2018. The rising tide: Local structural determinants of the radical right-wing vote in Switzerland. Comp Eur Polit 16, 602-619. https://doi.org/10.1057/s41295-016-0087-1

Turnbull-Dugarte, S.J., Rama, J., Santana, A., 2020. The Baskerville's dog suddenly started barking: voting for VOX in the 2019 Spanish general elections. Political Research Exchange 2, 1781543. https://doi.org/10.1080/2474736X.2020.1781543 